\title{
The Application of AHP in Electric Resource Evaluation
}

\author{
Chunlan Qiu \& Yonglin Xiao \\ Library of Jiangxi Science and Technology University \\ Ganzhou 341000, China \\ E-mail:jxust@163.com
}

\begin{abstract}
This article utilizes the analytic hierarchy process (AHP) method to study and establish the hierarchy model and its evaluation system for the electric resource evaluation.
\end{abstract}

Keywords: AHP, Electric resource, Evaluation system

\section{Introduction}

In recent years, with the continual increase of electric resource, the purchasing of electric resource has becoming the important part of the construction of library literature resource. The outlay used in electric resource in many libraries has exceeded $25 \%$, so whether for purchasing new electric resource or continuing order and maintaining present electric resource, a new problem occurs, i.e. how to select and evaluate the electric resource, and how to enhance benefits and make the construction of electric resource more reasonable and scientific through the evaluation of electric resource?

However, present scholars' researches only focused on the evaluation of internet information resource or single database, and there are few researches to study the integrated evaluation to the collection of electric resource, and the evaluation and system are not perfect, the present evaluation methods include qualitative method and quantitative method. In this article, we will adopt the AHP method which combines qualitative analysis with quantitative analysis, and try to establish the electric resource evaluation system that can be applied in the pre-evaluation before purchasing and the after-evaluation in the purchasing.

The AHP method (Cai, 2005, p.58-63) was put forward by US famous operational research expert T. L Saaty in 1970s, which tried to simulate three human basic characters (i.e. decomposing, estimation and integration) to deal with complex problems through analytic hierarchy, quantitative analysis and standardization, and added statistical test in the whole process. It adapts to solve those decision problems that have complex structure and many decision rules and are difficult to be quantified.

The basic approach of AHP method include following steps. (1) Establish the concept of the complex problem and find out main factors involved in the study objective. (2) Analyze the association and subjection relationships among factors and establish orderly ladder hierarchy model. (3) Compare both relative essentialities of various factors on the same layer to the certain rule on the upper layer, and establish the evaluation matrix. (4) Compute the relative weight of the compared factor to the rule on the upper layer according to the evaluation matrix and implement the coherence test. (5) Compute the integrated weight of various layers to the total objective of the system and implement total compositor of the layers.

\section{Establishment of electric resource evaluation system}

\subsection{Establishing hierarchy model}

Base on many evaluation indexes of electric resource, we build a ladder hierarchy model (Xiang, 2004, p.26-29 \& Wang, 2005, p.67-70 \& Xiao, 2002, p.35-42) (seen in Figure 1, the 3rd index are not be concretely explained, which are seen in Table 4).

\subsection{Constructing comparison evaluation matrix}

We adopt the 1-9 standard degree method (seen in Table 1) to evaluate the relative essentialities of the indexes, and evaluate the proportion degree of the relative essentiality through both comparison among them.

For example, for electric resource, we think the content of database is comparatively more important than the searches system and function and endows it 3 points, and it is more important than the uses and endows it 4 points, and it is little more important than the cost accounting and endows it 2 points, and it is more important than the manufacturer than manufacturer service and endows it 4 points, and in this way, we can establish A-B evaluation matrix (seen in Table 2).

Analogously, we can establish evaluation matrixes $\mathrm{B}_{1}-\mathrm{C}, \mathrm{B}_{2}-\mathrm{D}, \mathrm{B}_{3}-\mathrm{E}, \mathrm{B}_{4}-\mathrm{F}, \mathrm{B}_{5}-\mathrm{G}, \mathrm{C}_{1}-\mathrm{P}, \mathrm{C}_{2}-\mathrm{P}, \mathrm{C}_{3}-\mathrm{P}, \mathrm{C}_{4}-\mathrm{P}, \mathrm{C}_{5}-\mathrm{P}, \mathrm{C}_{6}-\mathrm{P}, \mathrm{C}_{7}-\mathrm{P}$, 
$D_{1}-P, D_{2}-P, D_{3}-P, D_{4}-P, E_{1}-P, E_{2}-P, E_{3}-P, E_{4}-P, F_{1}-P, F_{2}-P, F_{3}-P, F_{4}-P, F_{5}-P, G_{1}-P, G_{2}-P, G_{3}-P, G_{4}-P, G_{5}-P$.

\subsection{Computing the weights $W_{I}$ of various indexes}

The information base of AHP is the evaluation matrix, and it utilizes the compositor principle to obtain the matrix compositor vector and compute the weight coefficients of various indexes. The computation approach (Li, 2004, p.75-78) includes following steps.

(1) Compute the product $\mathrm{M}_{\mathrm{i}}$ of factors on every raw of the evaluation matrix $\mathrm{B}: \mathrm{M}_{\mathrm{i}}=\prod_{j=1}^{n} b_{j}, \mathrm{j}=1,2 \ldots \mathrm{n}$.

(2) Compute the root of $\mathrm{n}$ of $\mathrm{M}_{\mathrm{i}}$ on every raw: $\mathrm{w}_{\mathrm{i}}=\sqrt[n]{M_{i}}, \mathrm{i}=1,2 \ldots \mathrm{n}$, and $\mathrm{n}$ is the order number of the matrix in the equation.

(3) Implement normalized processing to $\left(\mathrm{w}_{1}, \mathrm{w}_{2} \ldots \mathrm{wn}\right)^{\mathrm{T}}$, and make $\mathrm{W}_{\mathrm{I}}=\underline{w_{i}}$, so $\mathrm{W}_{\mathrm{I}}=[\mathrm{W} 1, \mathrm{~W} 2, \ldots \mathrm{Wn}]^{\mathrm{T}}$ are the

$$
\sum_{j=1}^{n} w_{j}
$$

eigenvectors, i.e. the weighted coefficients of various indexes.

The concrete evaluations of various layer index weights are seen in Table 4.

\subsection{Implementing coherence testing to various evaluation matrix}

Because of the complexity of things and human difference of objective evaluation, every evaluation can not achieve completely identical, and to ensure the rationality of the conclusion of AHP method, we need to implement coherence test to various evaluation matrix, so we introduce the negative square values of other latent roots except for the maximum latent root of the evaluation matrix in AHP method and take them as the deviation coherence index of the matrix departures, i.e. use $\mathrm{CI}=\frac{\lambda_{\max }-n}{n-1}$ to test the coherence of the evaluation thinking. The maximum latent root $\lambda_{\max }=\sum_{i=1}^{n} \frac{(A W)_{i}}{n W_{i}}$.

To test whether different evaluation matrixes have satisfactory coherence, we must introduce the average random coherence index RI value of the evaluation matrix, and RI values of 1-9 order evaluation matrixes can be seen in Table 3.

To the 1st and 2nd evaluation matrixes, they always have satisfactory coherence, but the order number exceeds 2 , the ratio of the coherence index CI with the some order random coherence index RI is called the random coherence ratio $\mathrm{CR}$, and when $\mathrm{CR}=\frac{C I}{R I}<0.10$, we think this evaluation matrix has satisfactory coherence, i.e. the thinking on various layers is coherent, the conclusion obtained by the AHP is coherent, or else, the evaluation matrix should be adjusted to make it possess satisfactory coherence.

The maximum latent roots of the evaluation matrixes are obtained by the computer program, and according to them we can obtain the coherence index CI and random coherence ratio $\mathrm{CR}$, and then we implement the coherence test, and the results are complete coherence or satisfactory coherence.

\subsection{Integrated weight}

Though above approach, we can only obtain the weighted vectors of a group of factor to the certain factor on its upper layer. To obtain the relative weights of various factors to the total objective, especially to obtain the compositor weights of various indexes on the lowest layer to the objective, i.e. "integrated weights", we need superincumbent computation and integrate weights under the single rule, and obtain the relative weight of every evaluation objective in the layer objective to the total objective and implement total evaluation coherence test layer by layer. Relative to the total objective, the integrated weights of various indexes can be denoted as $\mathrm{W}=\mathrm{a}_{\mathrm{i}} \mathrm{a}_{\mathrm{ij}} \mathrm{a}_{\mathrm{ijk}}$, where $\mathrm{a}_{\mathrm{i}}, \mathrm{a}_{\mathrm{ij}}$ and $\mathrm{a}_{\mathrm{ijk}}$ respectively are 1st, 2nd and 3rd class index weight. Then we implement total compositor to the relative weights.

So we can obtain a clear evaluation index system of electric resource (seen in Table 4).

Though confirming the evaluation grading (seen Table 5), we can evaluate various indexes of the electric resource evaluation system, and the method is to use the weighted adding method, multiply the evaluation value of every evaluation index with the corresponding weight of this index, obtain the weighted evaluation value of the index, add these weighted evaluation values and obtain the total evaluation valves of the evaluation objective. The formula is $\mathrm{S}=\sum \mathrm{W}_{\mathrm{i}} \mathrm{P}_{\mathrm{i}}$ (here, $\mathrm{W}_{\mathrm{i}}$ is the integrated weight of the $\mathrm{i}^{\prime}$ th index, $\mathrm{P}_{\mathrm{i}}$ is the evaluation value of evaluated object on the $\mathrm{i}^{\prime}$ th index, and $i$ is the sequence number of the concrete index on the lowest layer in the evaluation model).

If the quantity of electric resources participated in the evaluation has Q1, Q2, Q3...Qn, we should adopt the AHP method. We respective establish evaluation matrixes aiming at 63 evaluation indexes, and obtain the compositor vectors 
of 63 evaluation matrixes. Multiply every compositor vector with weighted coefficient of corresponding index and add them, we can obtain the total compositor vector of Q1, Q2, Q3...Qn, and its result is also the compositor of the electric resources Q1, Q2, Q3...Qn.

\section{Conclusions}

The character of AHP is to combine qualitative analysis with quantitative analysis, which has high validity, reliability, conciseness and extensive applicability. But AHP still has limits, and its result only aims at the evaluation index in the rule layer, so the confirmation of evaluation index largely influences the system evaluation, in addition, human subjective evaluation has certain influence to the evaluation results of the system, so this method usually is combined with Delphi method to confirm the values of various indexes.

The evaluation of electric resources by AHP compensates human limit of subjective blur ability, which quantifies decision-makers' experiences and judgments, compares relative factors layer by layer, tests the rationality of comparison result layer by layer, avoids the subjective random of simple evaluation to make the result more exact and make the evaluation decision possess more objectivities and persuasions.

\section{References}

Cai, Haipeng \& Yang, Kunyu. (2005). Determining the Evaluation Criterion Weight of Digital Campus Based on AHP. Journal of Changsha Aeronautical Vocational and Technical College. No. 5(2). p. 58-63.

Li, Chaokui \& Tao, Weiguo. (2004). The Application of Analysis Hierarchy Process on the Evaluation of the Navigation System for Network Information Resources. Journal of the Library Science of Sichuan. No. 3. p. 75-78.

Wang, Hongfei. (2005). The Purchasing and Evaluation on Electronic Analysis Resources. Researches in Library Science. No. 4. p. 67-70.

Xiang, Yingming, Tan, Yiman \& Linhuan. (2004). Research on Evaluation Method and Mathematical Model for Electronic Resources. Library Journal. No. 1. p. 26-29.

Xiaolong \& Zhang, Yuhong. (2002). On the Development of the Electronic Resources Evaluation System. Journal of Academic Libraries. No. 3. p. 35-42.

Table 1. 1-9 standard degree method

\begin{tabular}{|l|l|l|l|l|l|l|l|l|l|}
\hline $\begin{array}{l}\text { Comparison } \\
\text { between } \\
\text { index A and } \\
\text { index B }\end{array}$ & $\begin{array}{l}\text { Extremely } \\
\text { important }\end{array}$ & $\begin{array}{l}\text { Very } \\
\text { important }\end{array}$ & Important & $\begin{array}{l}\text { Little } \\
\text { important }\end{array}$ & equal & $\begin{array}{l}\text { Little } \\
\text { unequal }\end{array}$ & unimportant & $\begin{array}{l}\text { Very } \\
\text { unimportant }\end{array}$ & $\begin{array}{l}\text { Extremely } \\
\text { unimportant }\end{array}$ \\
\hline $\begin{array}{l}\text { Evaluation } \\
\text { value of } \\
\text { index A }\end{array}$ & 9 & 7 & 5 & 3 & 1 & $1 / 3$ & $1 / 5$ & $1 / 7$ & $1 / 9$ \\
\hline Remark & \multicolumn{2}{|l|}{ Taking $8,6,2,1 / 2,1 / 4,1 / 6,1 / 8$ as the middle values of above evaluations } \\
\hline
\end{tabular}

Table 2. Evaluation matrix

\begin{tabular}{|c|c|c|c|c|c|}
\hline $\mathrm{A}$ & $\mathrm{B}_{1}$ & $\mathrm{~B}_{2}$ & $\mathrm{~B}_{3}$ & $\mathrm{~B}_{4}$ & $\mathrm{~B}_{5}$ \\
\hline $\mathrm{B}_{1}$ & 1 & 3 & 4 & 2 & 4 \\
\hline $\mathrm{B}_{2}$ & $1 / 3$ & 1 & 3 & 2 & 3 \\
\hline $\mathrm{B}_{3}$ & $1 / 4$ & $1 / 3$ & 1 & $1 / 3$ & 1 \\
\hline $\mathrm{B}_{4}$ & $1 / 2$ & $1 / 2$ & 3 & 1 & 3 \\
\hline $\mathrm{B}_{5}$ & $1 / 4$ & $1 / 3$ & 1 & $1 / 3$ & 1 \\
\hline
\end{tabular}

Table 3. RI values of evaluation matrix

\begin{tabular}{|l|l|l|l|l|l|l|l|l|l|}
\hline Order number & 1 & 2 & 3 & 4 & 5 & 6 & 7 & 8 & 9 \\
\hline RI & 0.00 & 0.00 & 0.58 & 0.90 & 1.12 & 1.24 & 1.32 & 1.41 & 1.45 \\
\hline
\end{tabular}


Table 4. Evaluation index system table of electric resource

\begin{tabular}{|c|c|c|c|c|}
\hline \multirow{42}{*}{$\begin{array}{c}\text { A } \\
\text { electric } \\
\text { resource }\end{array}$} & 1st index $\left(a_{i}\right)$ & 2nd index $\left(a_{\mathrm{ij}}\right)$ & $3 \mathrm{rd}$ index $\left(\mathrm{a}_{\mathrm{ijk}}\right)$ & $\begin{array}{l}\text { Integrated } \\
\text { weight W }\end{array}$ \\
\hline & \multirow{19}{*}{$\begin{array}{c}\text { Contents of database } \\
\qquad B_{1} \\
(0.41)\end{array}$} & \multirow{4}{*}{$\begin{array}{l}\text { Embodied content } \\
\qquad \mathrm{C}_{1} \\
(0.34)\end{array}$} & Knowledge range $\mathrm{P}_{1}(0.33)$ & 0.0460 \\
\hline & & & Magazine sorts $P_{2}(0.17)$ & 0.0236 \\
\hline & & & $\begin{array}{l}\text { Article periodical proportion } \\
\mathrm{P}_{3}(0.17)\end{array}$ & 0.0236 \\
\hline & & & $\begin{array}{l}\text { Nuclear periodical proportion } \\
\mathrm{P}_{4}(0.33)\end{array}$ & 0.0460 \\
\hline & & $\begin{array}{c}\text { Fixed number of } \\
\text { year of data } C_{2} \\
(0.09) \\
\end{array}$ & Database time limit $\mathrm{P}_{5}(1.00)$ & 0.0369 \\
\hline & & \multirow{3}{*}{$\begin{array}{l}\text { Data type } \mathrm{C}_{3} \\
\quad(0.23)\end{array}$} & Article database $\mathrm{P}_{6}(0.50)$ & 0.0472 \\
\hline & & & Tabloid database $\mathrm{P}_{7}(0.25)$ & 0.0236 \\
\hline & & & Reality database $\mathrm{P}_{8}(0.25)$ & 0.0236 \\
\hline & & \multirow{3}{*}{$\begin{array}{c}\text { Data repetition ratio } \\
\qquad \mathrm{C}_{4} \\
(0.05)\end{array}$} & $\geq 30 \% \mathrm{P}_{9}(0.10)$ & 0.0020 \\
\hline & & & $10 \% \sim 30 \% \mathrm{P}_{10}(0.25)$ & 0.0051 \\
\hline & & & $\leq 10 \% \mathrm{P}_{11}(0.65)$ & 0.0133 \\
\hline & & \multirow{3}{*}{$\begin{array}{l}\text { Data update/lag } \mathrm{C}_{5} \\
(0.15)\end{array}$} & Daily update $\mathrm{P}_{12}(0.65)$ & 0.0400 \\
\hline & & & Weekly update $\mathrm{P}_{13}(0.25)$ & 0.0154 \\
\hline & & & Monthly update $\mathrm{P}_{14}(0.10)$ & 0.0062 \\
\hline & & \multirow{2}{*}{$\begin{array}{l}\text { Data source } \mathrm{C}_{6} \\
(0.09)\end{array}$} & Data credibility $\mathrm{P}_{15}(0.50)$ & 0.0184 \\
\hline & & & $\begin{array}{l}\text { Information provider's reputation } \\
\mathrm{P}_{16}(0.50)\end{array}$ & 0.0184 \\
\hline & & \multirow{3}{*}{$\begin{array}{c}\text { Information } \\
\text { resource } \\
\text { organization } \mathrm{C}_{7} \\
(0.05)\end{array}$} & $\begin{array}{l}\text { Classifying according to topic and } \\
\text { subject } \mathrm{P}_{17}(0.40)\end{array}$ & 0.0082 \\
\hline & & & $\begin{array}{c}\text { Rationality of classification } \mathrm{P}_{18} \\
(0.40)\end{array}$ & 0.0082 \\
\hline & & & Frame structure $\mathrm{P}_{19}(0.20)$ & 0.0041 \\
\hline & \multirow{21}{*}{$\begin{array}{l}\text { Searches system and } \\
\text { functions } B_{2} \\
(0.24)\end{array}$} & \multirow{4}{*}{$\begin{array}{c}\text { Searches function } \\
\mathrm{D}_{1} \\
(0.35)\end{array}$} & Browse searches $\mathrm{P}_{20}(0.10)$ & 0.0084 \\
\hline & & & Simple searches $P_{21}(0.16)$ & 0.0134 \\
\hline & & & Second time searches $\mathrm{P}_{22}(0.28)$ & 0.0235 \\
\hline & & & Checkable field $\mathrm{P}_{23}(0.46)$ & 0.0386 \\
\hline & & \multirow{6}{*}{$\begin{array}{c}\text { Searches technology } \\
\qquad \mathrm{D}_{2} \\
(0.35)\end{array}$} & Boolean searches $\mathrm{P}_{24}(0.20)$ & 0.0168 \\
\hline & & & Truncate searches $\mathrm{P}_{25}(0.20)$ & 0.0168 \\
\hline & & & Quotation searches $\mathrm{P}_{26}(0.20)$ & 0.0168 \\
\hline & & & Clustering searches $\mathrm{P}_{27}(0.20)$ & 0.0168 \\
\hline & & & Position logic $\mathrm{P}_{28}(0.10)$ & 0.0084 \\
\hline & & & Weight searches $\mathrm{P}_{29}(0.10)$ & 0.0084 \\
\hline & & \multirow{5}{*}{$\begin{array}{l}\text { Searches results } \mathrm{D}_{3} \\
(0.19)\end{array}$} & Completely exact $\mathrm{P}_{30}(0.43)$ & 0.0196 \\
\hline & & & Output format $\mathrm{P}_{31}(0.27)$ & 0.0123 \\
\hline & & & Hyperlink $\mathrm{P}_{32}(0.10)$ & 0.0046 \\
\hline & & & Compositor mode $\mathrm{P}_{33}(0.10)$ & 0.0046 \\
\hline & & & Marker $\mathrm{P}_{34}(0.10)$ & 0.0046 \\
\hline & & \multirow{6}{*}{$\begin{array}{l}\text { User service } \mathrm{D}_{4} \\
\quad(0.11)\end{array}$} & Help document $\mathrm{P}_{35}(0.37)$ & 0.0100 \\
\hline & & & User training $\mathrm{P}_{36}(0.24)$ & 0.0063 \\
\hline & & & Word and table tool $\mathrm{P}_{37}(0.15)$ & 0.0040 \\
\hline & & & $\begin{array}{l}\text { Adjustment of searches interface } \\
\mathrm{P}_{38}(0.08)\end{array}$ & 0.0021 \\
\hline & & & Searches history record $\mathrm{P}_{39}(0.08)$ & 0.0021 \\
\hline & & & $\begin{array}{l}\text { Literature transfer service } \mathrm{P}_{40} \\
(0.08)\end{array}$ & 0.0021 \\
\hline & $\begin{array}{c}\text { Uses } B_{3} \\
(0.08)\end{array}$ & $\begin{array}{l}\text { Entry time } \mathrm{E}_{1} \\
\quad(0.12)\end{array}$ & Database opened time $\mathrm{P}_{41}(1.00)$ & 0.0096 \\
\hline
\end{tabular}




\begin{tabular}{|c|c|c|c|}
\hline & $\begin{array}{l}\text { Searches time } E_{2} \\
(0.23)\end{array}$ & Searches mode used time $\mathrm{P}_{42}(1.00)$ & 0.0184 \\
\hline & $\begin{array}{c}\text { Download } \\
\text { tabloid/entire article } \\
\text { E }_{3} \\
(0.23)\end{array}$ & $\begin{array}{l}\text { Article number downloaded to the } \\
\text { client computer } \mathrm{P}_{43}(1.00)\end{array}$ & 0.0184 \\
\hline & User evaluation $\mathrm{E}_{4}$ & Easily using character $\mathrm{P}_{44}(0.33)$ & 0.0111 \\
\hline & $(0.42)$ & Practicability $\mathrm{P}_{45}(0.67)$ & 0.0225 \\
\hline \multirow{5}{*}{$\begin{array}{l}\text { Cost accounting } \mathrm{B}_{4} \\
(0.19)\end{array}$} & $\begin{array}{c}\text { Data base price } \mathrm{F}_{1} \\
(0.48)\end{array}$ & Unit price of database $\mathrm{P}_{46}(1.00)$ & 0.0912 \\
\hline & $\begin{array}{c}\text { Searches cost } F_{2} \\
(0.12)\end{array}$ & Cost of database searches $\mathrm{P}_{4}(1.00)$ & 0.0228 \\
\hline & $\begin{array}{c}\text { Entry cost } F_{3} \\
(0.12)\end{array}$ & Cost of database entry $\mathrm{P}_{48}(1.00)$ & 0.0228 \\
\hline & $\begin{array}{l}\text { Investment of } \\
\text { hardware and } \\
\text { software } \mathrm{F}_{4} \\
(0.21)\end{array}$ & $\begin{array}{l}\text { Cost to purchasing equipment and } \\
\text { software } \mathrm{P}_{49}(1.00)\end{array}$ & 0.0399 \\
\hline & $\begin{array}{c}\text { System maintenance } \\
\mathrm{F}_{5} \\
(0.07)\end{array}$ & Professional maintenance $\mathrm{P}_{50}(1.00)$ & 0.0133 \\
\hline \multirow{13}{*}{$\begin{array}{l}\text { Manufacturer services } \\
\qquad \mathrm{B}_{5} \\
(0.08)\end{array}$} & \multirow{3}{*}{$\begin{array}{c}\text { Data transfer mode } \\
\mathrm{G}_{1} \\
(0.31)\end{array}$} & International network $\mathrm{P}_{51}(0.16)$ & 0.0040 \\
\hline & & Special line mode $\mathrm{P}_{52}(0.30)$ & 0.0074 \\
\hline & & Local mode $\mathrm{P}_{53}(0.54)$ & 0.0134 \\
\hline & \multirow{3}{*}{$\begin{array}{l}\text { Probation time } \mathrm{G}_{2} \\
\qquad(0.10)\end{array}$} & Below 6 months $\mathrm{P}_{54}(0.54)$ & 0.0043 \\
\hline & & $3 \sim 6$ months $\mathrm{P}_{55}(0.30)$ & 0.0024 \\
\hline & & Below 3 months $\mathrm{P}_{56}(0.16)$ & 0.0013 \\
\hline & \multirow{3}{*}{$\begin{array}{l}\text { Visiting mode } \mathrm{G}_{3} \\
\qquad(0.18)\end{array}$} & Password entry $\mathrm{P}_{57}(0.40)$ & 0.0058 \\
\hline & & IP limit $\mathrm{P}_{58}(0.40)$ & 0.0058 \\
\hline & & Concurrent user $\mathrm{P}_{59}(0.20)$ & 0.0029 \\
\hline & \multirow{2}{*}{$\begin{array}{c}\text { Technology support } \\
\mathrm{G}_{4} \\
(0.31) \\
\end{array}$} & User service $\mathrm{P}_{60}(0.67)$ & 0.0166 \\
\hline & & Visiting purview $\mathrm{P}_{61}(0.33)$ & 0.0081 \\
\hline & \multirow{2}{*}{$\begin{array}{c}\text { Relative document } \\
\mathrm{G}_{5} \\
(0.10)\end{array}$} & MARC record provision $\mathrm{P}_{62}(0.67)$ & 0.0054 \\
\hline & & $\begin{array}{c}\text { ISSN, web address information } \\
\text { provision } \mathrm{P}_{63}(0.33)\end{array}$ & 0.0026 \\
\hline
\end{tabular}

Notice: The numbers in the bracket are the weights relative to superior indexes.

Table 5. Evaluation grading

\begin{tabular}{|c|c|c|c|c|c|}
\hline Grading & good & $\begin{array}{c}\text { comparatively } \\
\text { good }\end{array}$ & general & $\begin{array}{c}\text { comparatively } \\
\text { bad }\end{array}$ & bad \\
\hline Value interval & $10-8$ & $8-6$ & $6-4$ & $4-2$ & $2-0$ \\
\hline
\end{tabular}




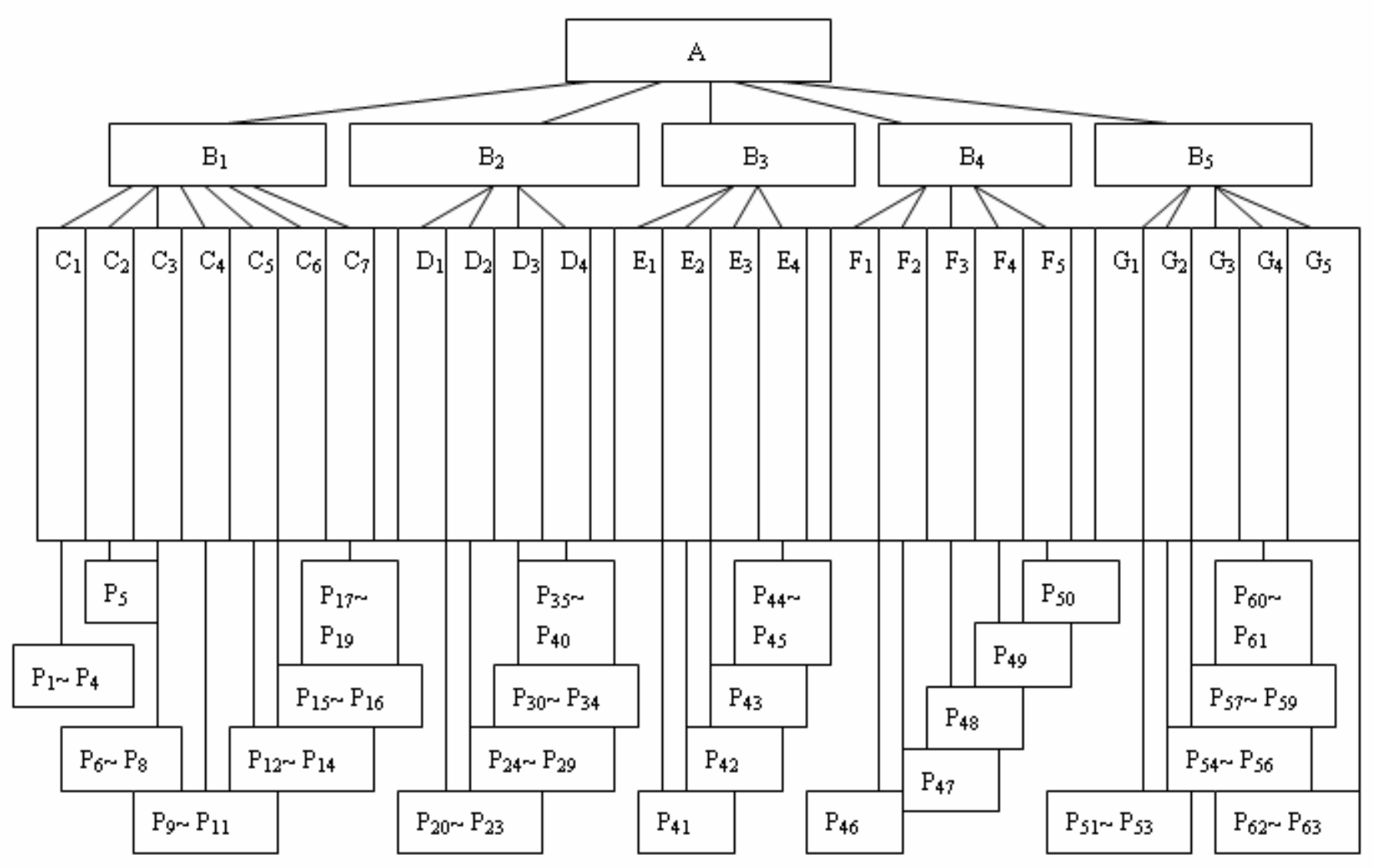

Figure 1. Ladder Hierarchy Model

Notice: A- the evaluation of electric resource, $B_{1}$ - the contents of database, $B_{2}$ - searches system and function, $B_{3}$ - uses, $\mathrm{B}_{4^{-}}$cost accounting, $\mathrm{B}_{5^{-}}$manufacturer service, $\mathrm{C}_{1^{-}}$embodied content, $\mathrm{C}_{2^{-}}$fixed number of year of data, $\mathrm{C}_{3^{-}}$data type, $\mathrm{C}_{4^{-}}$data repetition ratio, $\mathrm{C}_{5^{-}}$data update/lag, $\mathrm{C}_{6^{-}}$data source, $\mathrm{C}_{7^{-}}$information resource organization, $\mathrm{D}_{1^{-}}$searches function, $\mathrm{D}_{2^{-}}$searches technology, $\mathrm{D}_{3^{-}}$searches results, $\mathrm{D}_{4^{-}}$user service, $\mathrm{E}_{1^{-}}$entry time, $\mathrm{E}_{2^{-}}$searches time, $\mathrm{E}_{3^{-}}$ download tabloid/entire article, $\mathrm{E}_{4}$ - user evaluation, $\mathrm{F}_{1}$ - data base price, $\mathrm{F}_{2}$ - searches cost, $\mathrm{F}_{3}$ - entry cost, $\mathrm{F}_{4}$ - investment of hardware and software, $F_{5^{-}}$system maintenance, $\mathrm{G}_{1}$ - data transfer mode, $\mathrm{G}_{2^{-}}$probation time, $\mathrm{G}_{3^{-}}$visiting mode, $\mathrm{G}_{4^{-}}$ technology support, $\mathrm{G}_{5}$ - relative document. 